\title{
İsmail Kara. Bir Düşünce Tarihi Metni Olarak İstiklâl Marşı. İstanbul Dergâh, 2021, 223 sayfa. ISBN:
} 978-625-7660-40-2.

Umut Kaya*

\section{$\ddot{O ̈ z}$}

İstiklal Marşı, bu ülke toprakları üzerinde yaşayanlar için bir şiirden, bir marştan çok daha ötesini temsil etmektedir. Bu önemli metin İsmail Kara tarafından ilk defa şerh/tahlil edilmiştir. Yazar bu tahlilini, edebi, Mehmet Akif' in kendisi ve marşın yazıldığı dönemdeki temel düşünsel tartışmalar etrafında yapmıştır. Yazar birinci el kaynakları kullandığı bu çalışmasında, İstiklal Marşı’nın dini-milli bir metin olduğuna vurgu yapmaktadır. İsmail Kara bu çalışmada, İstiklal Marşı'nı tahlil ederken, aynı zamanda marşın yazıldığı dönemin de fotoğrafını çekmektedir. Sonuç olarak bu kitap, okuyucularına ülkemizde yaşanan düşünsel değişimleri İstiklal Marşı özelinde göstermesi bakımından herkese tavsiye edilebilecek bir eserdir.

\section{Anahtar Kelimeler}

İstiklal Marşı, İsmail Kara, Cumhuriyet Dönemi Türk Düşünce Tarihi

\begin{abstract}
Independence March represents much more than a poem and an anthem for those living on the territory of this country. This important text was interpreted/analyzed for the first time by İsmail Kara. The author made this analysis around the literary, Mehmet Akif herself and the main intellectual debates at the time the anthem was written. In this study, in which first hand sources are used, it is emphasized that Independence March is a religiousnational text. In this study, İsmail Kara, while analyzing Independence March, also takes a photo of the period when the anthem was written. As a result, this book is a work that can be recommended to everyone.
\end{abstract}

\section{Keywords}

Independence March, İsmail Kara, Turkish Thought History in the Republican Period

\footnotetext{
* Doç. Dr., Marmara Üniversitesi İlahiyat Fakültesi, Din Eğitimi Anabilim Dalı, umut.kaya@marmara.edu.tr. ORCID: 0000-0002-3237-8150
} 


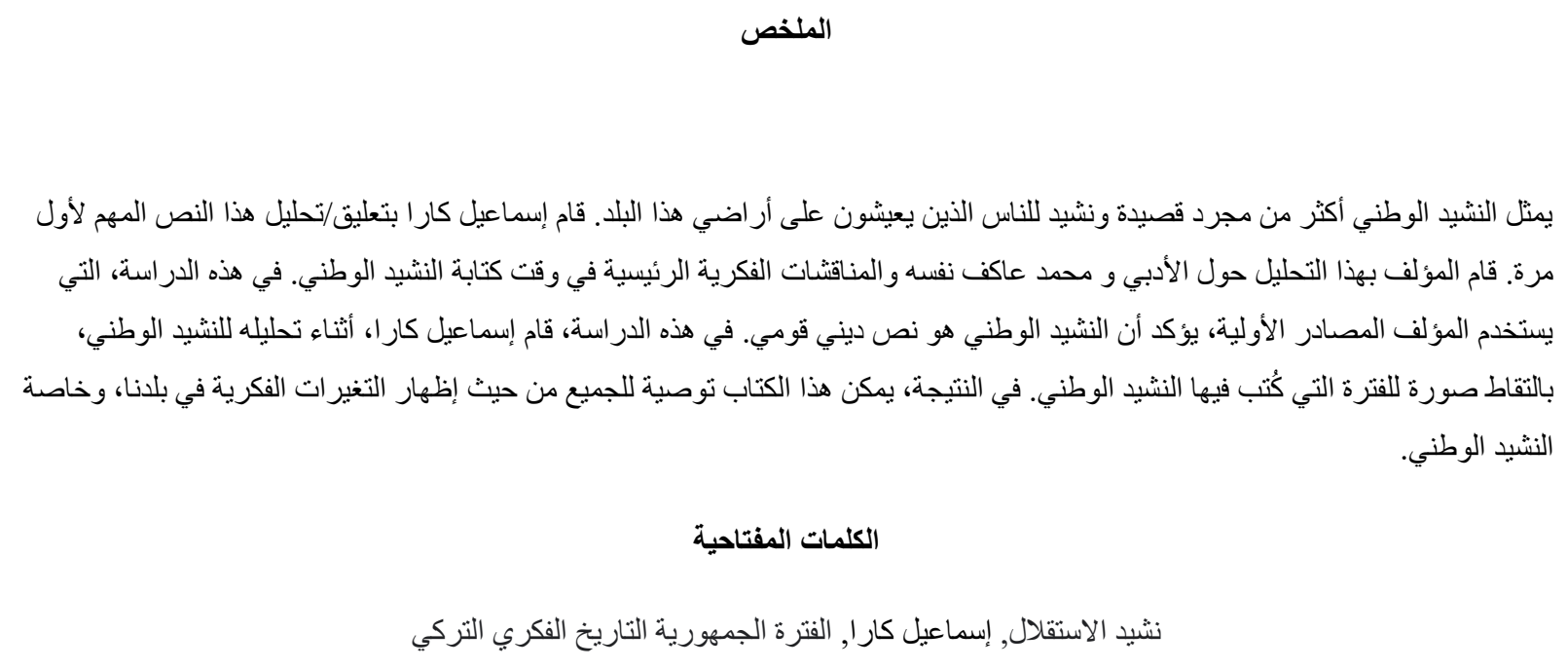

İstiklal Marşı, bu ülke toprakları üzerinde yaşayanlar için bir şiirden, bir marştan çok daha ötesini temsil etmektedir. İşte böyle bir ortamda İsmail Kara, kendi deyimiyle 1924'den beri "meşâhir-i meçhule" (meçhul kalmış meşhur) kalan İstiklal Marşı'nı ele almayı hedeflemişsir. Yazar bunu birbiri ile iç içe geçmiş üç halka/kademe üzerinden yapmayı hedeflediğini okuyucularına duyurmaktadır. Yazarın belirtmiş olduğu kademelerden ilki, İstiklal Marşı'nın bizzat kendisini edebî-fikrî müstakil bir manzume olarak ele alarak tahlil etmektir. İkinci kademe ise Mehmet Akif'in hayatını işini içine katarak metni şerh etmektir. Üçüncü kademe ise çağdaş İslam Türk düşüncesinin dönem içindeki ana kavramları, tartışmaları üzerinden metni ele almaktır. Bu doğrultuda yazar, İstiklal Marşı'nı kıta kıta tahlil yapmak yerine, İstiklal Marşı tahlilini marşı ortaya çıkaran temel temalar üzerinden yapmaktadır. Kitabın bölümlerini oluşturan bu temalar ise istiklal, millet, din, vatan, medeniyet, ümittir. Kara, bu temaları açılarken İstiklal Marşı'nda geçen hürriyet, vefa, ezan, izmihlal, darü'l-İslam, yurt gibi kavramları açıklamak suretiyle İstiklal Marşı’nın dini-milli bir metin olduğuna vurgu yapmaktadır. (s. 79) Yazar, bu kavramları açıklarken oldukça uzun dipnotlara ve alıntılara yer vermiştir. Yazar, bu alıntılarda -kendine has şekilde daha önceki eserlerinden de bildiğimiz-, önemli gördüğü kavramları, "vurgular bizim” demek suretiyle italik olarak okuyucusuyla paylaşarak, metinde okuyucunun dikkat etmesi gereken yerleri de işaret etmektedir.

İsmail Kara eserin giriş bölümünde "İstiklâl/İstikbal Şiirinin Doğuşu” başlıklı bir giriş yazısına, kitabın sonunda ise "Sonuç Yerine: Düne, Bugüne ve Yarına Dair Birkaç Mesele" başlı̆̆ı altında genel bir değerlendirmeye yer vermiştir. Kitabın en sonunda ise İstiklal Marşı’nın tahlilinde en çok müracaat edilen 3 parçanın tam metni ile İstiklal Marşı'nın kabul sürecini anlatan Sebîlürreşâd' da çıkan bir yazıya yer verilmiştir. Eserin sonunda verilen diğer metinler, Çanakkale Şehitlerine, Nasrullah Kürsüsünde ve Bülbül isimli parçalardır.

Kara, İstiklal Marşı ile tahlilinin ilk kademesinde birinci el kaynakları kullanmaktadır. Marşın yazılış sürecinde ve sonrasında yaşananları tarihi ve kaynakları ile beraber ortaya koymaktadır. Marşta geçen kavramları sözlüklerden, dönemin gazetelerinden, TBMM tutanaklarından, biyografilerden yararlanarak dönem içindeki anlam kaymalarına da yer vererek açıklamaya çalışmaktadır. Özellikle millet, istiklal, medeniyet, darü’l-İslam gibi kavramların anlamlarında yaşanan değişimleri kronolojik olarak görmek okuyucu açısından oldukça ilgi çekici olmuştur. 
İkinci kademede ise yazar, Akif'in düşünsel dünyasına yer vererek tahlillerine devam etmektedir. Yazar, burada yer yer Mehmet Akif portresi de çizerek aslında marşa bir de bu zaviyeden bakılmasını istemektedir. Bu doğrultuda Safahat'tan ve Akif'in Safahat'ta yer almayan diğer şiir ve yazılarından faydalanmaktadır. Bu konuda özellikle başvurulan eserlerden birisi de Çanakkale Şehitlerine isimli şiirdir. Yazar, İstiklal Marşı'nı zaman zaman Çanakkale destanı üzerinden okuma yaparak yorumlamakta, Çanakkale destanını adeta İstiklal Marşı'nın habercisi, müjdeleyicisi olarak sunmaktadır. (s. 80, 128) Yazara göre Akif, tam da milli mücadelenin ortasında yer alan bir mücadele adamı ve şairdir.

Tahlilin üçüncü kademesinde ise yazar, dönemin düşünsel yapısına yer vermektedir. Bu sayfalarda Kara’nın dönemin düşünce yapısına ne kadar vakıf olduğunu görmek mümkündür. Kara, Akif'in kafasında oluşturduğu düşünce sistemini ve İstiklal Marşı'nı yazarken kafasındaki düşünce dünyasını, bunları oluşturan yapı taşlarının hangi kaynaklardan beslendiğini, bunlara etki eden faktörleri çok güzel bir şekilde tespit ve tahlil etmektedir. (s. 96-97) Hatta bu konuda Kara’nın, Akif' in düşünce yapısının geçtiği tecrübe ve arayışları adeta bir dedektif gibi izini sürerek açıkladığını söylemek yanlış olmaz. Ayrıca eserde Akif’in düşünce yapısıyla beraber dönemin düşünsel yapısı da okuyucuya aktarılmakta, bu bakımdan İstiklal Marşı birbiri ile bağlantılı üç farklı yönden tahlil edilmektedir.

Yazar, Akif'in düşünce yapısını okuyucularına aktarırken sadece İstiklal Marşı öncesini değil, sonrasındaki düşünce ve hislerini de okuyucularına aktarmaktadır. Türk milleti için çok kutsal bir yerde konumlandırılan ezanın, milli mücadele görmüş askerler, bürokratlar, siyasetçiler eliyle Türkçe okutturulması karşısında Akif’in iç dünyasında yaşadığı fırtınalar, bunun en güzel örneklerindendir. (86-87)

Yazar, İstiklal Marşı'nı şerh ederken dönemin fotoğrafını çekip, İstiklal Marşı merkezinde dönemin gelişmelerini de yorumlamaktadır. (s. 77-78) Bu bakımdan eser, Cumhuriyet sonrası düşünce tarihimiz açısından da incelenmeye değerdir. Bu doğrultuda yazar, İstiklal Marşı'nın hem dini hem de milli bir metin olduğunu güçlü bir şekilde vurgulamakta, bahsedilen dönem okuma ve yorumlamalarını ise bu minvalde yapmaktadır. (s. 79)

Eserin sonuç kısmında ise İsmail Kara, çok çarpıcı tespitlere yer vermiştir. Esasen yazarın bu tespitleri yeni kurulan Türk devletinin bürünmüş olduğu yeni laik-seküler çizgide, İstiklal Marşı gibi içinde dini simgeler barındıran bir metne hatta milli marşa bakışlarını gözler önüne sermektedir. Yazar, Lozan sonrasında oluşan bu düşünce yapısı ile birlikte "İslam'ın paranteze” alındığını, bununla ilişkili olarak da milli ve dini bir metin olarak görülen “İstiklal Marşı”’nın da derinliğine kavranılamaz bir yere doğru sevk edildiğini ifade etmektedir. Kara, Mustafa Kemal Paşa'nın Nutuk'ta milli mücadelenin tam ortasında duran bir kişiden yani Akif'ten ve onun yazdığı İstiklal Marşı'ndan bilinçli bir şekilde bahsetmemesini ve aynı şekilde Kazım Karabekir tarafindan İstiklal Marşı yerine bir marş teklif edilmesini, bu kafa yapısının çalışma tarzını göstermesi bakımından da önemli olduğunu ifade etmektedir.

Yazarın akademik bir üslupla kaleme aldığı bu kitapta, bazı yazım yanlışlarına rastlanılsa da bunların kitabın ilk basımı olduğu göz önüne alındığında normal karşılanması gerekir. Yine de kitabın sonraki basımlarında düzeltilir ümidiyle söz konusu yazım hatalarının paylaşılması yerinde olacaktır: tazda/tarzda (s. 70), külüründen/kültüründen (s.86), Nusrullah/ Nasrullah (s. 103), payaşalım /paylaşalım (s.136), iâhîsinin/ilâhîsinin (s.138), kuratırıcı / kurtarıcı (s.140), düşüncesile/düşüncesiyle (s. 155). 
Kitapta okuyucuyu zorlayan hususlardan bir tanesi ise diğer sayfaya taşan dipnotların metinle karıştırılma ihtimalidir. Söz konusu uzun dipnot ve parantez içi cümleleri, metin içinde başka bir metin okunuyor intibaı verse de son derece yerinde bilgilendirmeler olduğunu belirtmek gerekir. Bunun yanında birkaç sayfada ise dizgiden kaynaklanan sebeplerle sayfa içinde hangisinin metin, hangisinin dipnot olduğunu ayırt etmenin bir bakışta mümkün olmadığını söylemek gerekir. (103, 122, 125, 128 ve 129. sayfalar) Bu durumun dikkatli okuyucular için sorun teşkil edecek tarzda olmadığını da belirtmekte fayda var. Yine de diğer basımlarda basit bir dizgi düzeltimi ile bunun önüne geçmek mümkün görünmektedir. Son olarak kitapta eksik olarak görülen bir kısım da, kitabın sonunda müstakil olarak bir bibliyografyaya yer verilmemesi olmuştur. Kitapta her ne kadar kullanılan kaynaklar dipnotlarda referans olarak gösterilse de kitabın sonunda müstakil olarak bir bibliyografyanın olmaması bir eksiklik olmuştur, denilebilir.

Sonuç olarak, değerlendirmesini yaptığımız bu kitap, okuyucularına ülkemizde yaşanan düşünsel değişimleri İstiklal Marşı özelinde göstermesi bakımından özellikle Cumhuriyet döneminde değisşen kavramlara merakı olan herkese tavsiye edilecek bir eserdir. 